Research Perspective

\title{
Balancing efficacy and quality of life measurements among metastatic renal cell carcinoma (RCC) studies
}

\author{
Jeanny B. Aragon-Ching ${ }^{1}$ \\ ${ }^{1}$ GU Medical Oncology, Inova Schar Cancer Institute, Fairfax, VA, USA \\ Correspondence to: Jeanny B. Aragon-Ching, email: jeanny.aragon-ching@inova.org \\ Keywords: mRCC; VEGF-TKI; Q-TWiST; CABOSUN trial \\ Received: March 15, $2021 \quad$ Accepted: March 16, $2021 \quad$ Published: March 21, 2021 \\ Copyright: @ 2021 Aragon-Ching. This is an open access article distributed under the terms of the Creative Commons Attribution License \\ (CC BY 3.0), which permits unrestricted use, distribution, and reproduction in any medium, provided the original author and source are \\ credited.
}

\begin{abstract}
Metastatic renal cell carcinoma ( $\mathrm{MRCC}$ ) treatments have rapidly evolved in the last few years. While vascular endothelial growth factor (VEGF) inhibition had previously been the mainstay of treatment for first-line advanced RCC therapy in the past decade, it has now rapidly changed into combination checkpoint inhibitors with or without VEGF TKIs, although there remains a role for VEGF tyrosine kinase inhibitor monotherapy for patients with favorable-risk disease and for those with intermediate and poor-risk disease with the use of cabozantinib. Perspectives on the Quality-adjusted survival Time without Symptoms of disease or Toxicity (Q-TWiST) analysis for the CABOSUN trial, as well as different aspects of efficacy regarding different first-line therapy for advanced or metastatic RCC are discussed herein.
\end{abstract}

Treatment of metastatic $\mathrm{RCC}$ has been rapidly evolving over the past few years. While the use of VEGF TKIs (vascular endothelial growth factors - tyrosine kinase inhibitors) had been the cornerstone of treatment for advanced or metastatic renal cell carcinomas (RCC) since the approval of sunitinib and pazopanib [1], it soon got supplanted by the advent of treatment with the use of immune-oncology (IO) drugs. The first line treatment using checkpoint inhibitor (CPI) drugs or IO drugs versus the combination of IO with VEGF TKIs are rapidly evolving. In addition, the second-line treatment with nivolumab monotherapy or VEGF-TKI treatment with cabozantinib, lenvatinib with everolimus, axitinib, have all shaped the landscape of treatment for $\mathrm{mRCC}$.

The first line therapy with mRCC spans the use of $\mathrm{IO} / \mathrm{IO}$ combination with Checkmate 214 using nivolumab and ipilimumab $[2,3]$, the IO/VEGF-TKI combination which are plentiful including the earliest combination with atezolizumab with bevacizumab in the IMmotion 151 trial [4], Keynote 426 which combines pembrolizumab and axitinib [5], Javelin Renal 101 using avelumab and axitinib [6], Checkmate 9ER with nivolumab and cabozantinib [7], as well as VEGF-TKI monotherapy with cabozantinib based on the CABOSUN trial [8], all with varying regulatory approval (see Table 1). On the other hand, newer studies including CLEAR [9], that evaluated pembrolizumab and lenvatinib, all have shown benefit over sunitinib alone. These first line trials assessed and evaluated different primary endpoints and have varying overall response rates but also different quality of life results. While overall survival has historically been used as the most important parameter of benefit, some of the combination therapies or monotherapy have been approved based on progression-free survival (PFS) alone. Therefore, choosing the most optimal patient population for specific types of therapy are also poorly defined.

Given the abundance of first-line studies available, all of which showing advantages in the primary endpoint that they were designed for and almost unanimously superior to sunitinib alone, it is increasingly difficult to determine which combination or treatment is ultimately suitable for which patients at the appropriate time in their disease course. Certainly, one important aspect of importance to evaluate is the quality of life. While toxicities in general are different with checkpoint inhibitor use versus VEGF TKI use, the combination brings about potential overlap in the adverse effects with the use of both these agents. While cross-comparison amongst different trials is not recommended, there are also important considerations regarding toxicity profile that would lead to better tolerability in the choice of different therapies. 


\begin{tabular}{|c|c|c|c|c|c|}
\hline Trial & $\begin{array}{l}\text { Phase of } \\
\text { trial/MOA }\end{array}$ & $\begin{array}{l}\text { Doses and arms } \\
\text { of therapy } \\
\text { (n) }\end{array}$ & $\begin{array}{l}\text { Primary End- } \\
\text { points }\end{array}$ & $\begin{array}{l}\text { Endpoints/ } \\
\text { Responses }\end{array}$ & Comments \\
\hline CABOSUN & $\begin{array}{l}\text { Phase II/ } \\
\text { TKI }\end{array}$ & $\begin{array}{l}\text { Cabozantinib } \\
60 \mathrm{mg} \text { vs. suni- } \\
\text { tinib } 50 \mathrm{mg} \text { daily } \\
(4 \text { weeks on } / 2 \\
\text { weeks off) } \\
(n=157)\end{array}$ & PFS & $\begin{array}{l}\text { PFS: } \mathrm{C}=8.2 \\
\text { mos vs. } \mathrm{S} \\
=5.6 \text { mos; } \\
\text { ORR: } \mathrm{C}= \\
33 \% \text { vs. } \mathrm{S}= \\
12 \%\end{array}$ & $\begin{array}{l}\text { FDA-approved } \\
\text { December 19, } \\
2017 \text { for first- } \\
\text { line advanced } \\
\text { RCC }\end{array}$ \\
\hline IMmotion 151 & $\begin{array}{l}\text { Phase III/ } \\
\text { PD-L1 + } \\
\text { TKI }\end{array}$ & $\begin{array}{l}\text { Atezolizumab } \\
1200 \mathrm{mg} \text { IV + } \\
\text { bevacizumab } 15 \\
\mathrm{mg} / \mathrm{kg} \text { IV q } 3 \\
\text { weeks (6-week } \\
\text { cycle) vs. suni- } \\
\text { tinib } 50 \mathrm{mg} \text { daily } \\
(4 \text { weeks on/2 } \\
\text { weeks off) } \\
(n=915) \\
\end{array}$ & $\begin{array}{l}\text { PFS in PD- } \\
\mathrm{L} 1+\text {; } \\
\mathrm{OS} \text { in ITT }\end{array}$ & $\begin{array}{l}\text { PFS in PD- } \\
\text { L1: Atezo + } \\
\text { Bev = } 11.2 \\
\text { mos vs } \mathrm{S}= \\
7.7 \text { mos; } \mathrm{P} \\
=0.02 ; \mathrm{OS}: \\
\text { Atezo }+\mathrm{Bev} \\
=\mathrm{NR} \text { vs } \mathrm{S} \\
=23.3 \mathrm{mos}\end{array}$ & $\begin{array}{l}\text { Not FDA-ap- } \\
\text { proved }\end{array}$ \\
\hline Checkmate 214 & $\begin{array}{l}\text { Phase III/ } \\
\text { PD-L1 and } \\
\text { CTLA-4 } \\
\text { inhibitor }\end{array}$ & $\begin{array}{l}\text { Nivolumab IV + } \\
\text { Ipilimumab } 1 \mathrm{mg} / \\
\mathrm{kg} \mathrm{x} 4 \mathrm{q} 3 \text { weeks } \\
\text { then Nivolumab } \\
\text { q } 2 \text { weeks vs. } \\
\text { sunitinib } 50 \mathrm{mg} \\
\text { daily } \\
(\mathrm{n}=1096)\end{array}$ & $\begin{array}{l}\text { OS, ORR and } \\
\text { PFS in inter- } \\
\text { mediate and } \\
\text { poor-risk }\end{array}$ & $\begin{array}{l}\text { N/I: } 18-\mathrm{mo} \\
\text { OS = 75\%; } \\
\text { mOS=NR; } \\
\text { ORR }=42 \% \\
\text { vs. S: } 18-\mathrm{mo} \\
\text { OS=60\%; } \\
\text { mOS }= \\
26 \text { mos; } \\
\text { ORR }=27 \% ;\end{array}$ & $\begin{array}{l}\text { FDA approved } \\
\text { on April 16, } \\
2018 \text { for inter- } \\
\text { mediate and } \\
\text { poor-risk }\end{array}$ \\
\hline $\begin{array}{l}\text { JAVELIN Renal } \\
101\end{array}$ & $\begin{array}{l}\text { Phase III/ } \\
\text { PD-L1 + } \\
\text { TKI }\end{array}$ & $\begin{array}{l}\text { Avelumab } 10 \mathrm{mg} \text { / } \\
\text { kg IV q2 weeks } \\
+ \text { Axitinib } 5 \mathrm{mg} \\
\text { BID (6-week } \\
\text { cycle) vs. suni- } \\
\text { tinib } 50 \mathrm{mg} \text { daily } \\
\text { ( } 4 \text { weeks on/2 } \\
\text { weeks off) } \\
(n=886) \\
\end{array}$ & $\begin{array}{l}\text { PFS, OS in } \\
\text { PD-L1+ }\end{array}$ & $\begin{array}{l}\text { mPFS: Ave } \\
+ \text { axi }=13.8 \\
\text { mos vs. S } \\
=7.2 \text { mos; } \\
\text { ORR: Ave }+ \\
\text { axi }=55.2 \% \\
\text { vs. } \mathrm{S}= \\
25.5 \%\end{array}$ & $\begin{array}{l}\text { FDA approved } \\
\text { on May } 14,2019 \\
\text { for front-line } \\
\text { treatment ad- } \\
\text { vanced RCC }\end{array}$ \\
\hline Checkmate 9ER & $\begin{array}{l}\text { Phase III/ } \\
\text { PD-L1 + } \\
\text { VEGF TKI }\end{array}$ & $\begin{array}{l}\text { Nivolumab } 240 \\
\text { mg IV q } 2 \text { weeks } \\
+ \text { cabozantinib } 40 \\
\text { mg po vs. suni- } \\
\text { tinib } 50 \mathrm{mg} \text { daily } \\
\text { ( } 4 \text { weeks on } / 2 \\
\text { weeks off) }(\mathrm{n}=\end{array}$ & $\begin{array}{l}\text { PFS as de- } \\
\text { termined by } \\
\text { BICR }\end{array}$ & $\begin{array}{l}\mathrm{mPFS} \mathrm{N} / \mathrm{C}= \\
16.6 \mathrm{mos} \mathrm{vs} \\
\mathrm{S}=8.3 \mathrm{mos}\end{array}$ & $\begin{array}{l}\text { FDA approved } \\
\text { on January 20, } \\
2021 \text { for ad- } \\
\text { vanced RCC }\end{array}$ \\
\hline
\end{tabular}




\begin{tabular}{|c|c|c|c|c|c|}
\hline KEYNOTE-426 & $\begin{array}{l}\text { Phase III/ } \\
\text { PD-1 + TKI }\end{array}$ & $\begin{array}{l}\text { Pembrolizumab } \\
200 \mathrm{mg} \text { IV q } 3 \\
\text { weeks + axitinib } \\
5 \mathrm{mg} \text { BID (6- } \\
\text { week cycle) vs. } \\
\text { sunitinib 50mg } \\
\text { daily (4 weeks } \\
\text { on } / 2 \text { weeks off) } \\
(n=840)\end{array}$ & PFS, OS & $\begin{array}{l}\text { mPFS: } \\
\text { Pem + axi } \\
=15.1 \text { mos } \\
\text { vs. } \mathrm{S}=11.1 \\
\text { mos; ORR: } \\
\text { Pem + axi } \\
=59.3 \% \text { vs. } \\
\mathrm{S}=35.7 \% \\
\mathrm{P}<0.001\end{array}$ & $\begin{array}{l}\text { FDA approved } \\
\text { on April 19, } \\
2019 \text { for first- } \\
\text { line treatment } \\
\text { advanced RCC }\end{array}$ \\
\hline $\begin{array}{l}\text { KEYNOTE-581/ } \\
\text { CLEAR }\end{array}$ & $\begin{array}{l}\text { Phase III/ } \\
\text { PD-1 + TKI }\end{array}$ & $\begin{array}{l}\text { Pembrolizumab } \\
200 \mathrm{mg} \text { IV q } 3 \\
\text { weeks + lenva- } \\
\text { tinib } 20 \mathrm{mg} / \text { day } \\
\text { vs. everolimus } 5 \\
\text { mg/day + len- } \\
\text { vatinib } 18 \mathrm{mg} / \\
\text { day vs. sunitinib } \\
50 \mathrm{mg} \text { daily } \\
\text { ( } 4 \text { weeks on/2 } \\
\text { weeks off) } \\
\text { ( } n=735 \text { ) }\end{array}$ & PFS & $\begin{array}{l}\text { PFS: Len }+ \\
\text { P = } 23.9 \text { mos } \\
\text { vs } \mathrm{S}=9.2 \\
\text { mos; Len }+ \\
\text { eve }=14.7 \\
\text { mos vs. } \mathrm{S}= \\
9.2 \text { mos; OS } \\
=\text { Len }+\mathrm{P} \\
\text { vs S; HR }= \\
0.66 ;\end{array}$ & $\begin{array}{l}\text { Not FDA approved } \\
\text { yet }\end{array}$ \\
\hline
\end{tabular}

VEGF = vascular endothelial growth factor; TKI = tyrosine kinase inhibitor; PD-1 = programmed cell death protein 1; PD$\mathrm{L} 1$ - programmed death-ligand $1 ; \mathrm{n}=$ number; $\mathrm{q}=$ every; $\mathrm{BID}=$ twice a day; $\mathrm{ORR}=$ objective response rate; $\mathrm{OS}=$ Overall survival; PFS = progression-free survival; $\mathrm{mPFS}=$ median PFS; $\mathrm{mOS}=$ median OS; ITT = intention-to-treat population; mos $=$ months; $\mathrm{AE}=$ adverse event; $\mathrm{DCR}=$ disease control rate; $\mathrm{Ave}=$ avelumab; $\mathrm{Axi}=$ axitinib; $\mathrm{BICR}=\mathrm{Blinded}$ independent central review; $\mathrm{S}=$ sunitinib; $\mathrm{N}$ = Nivolumab; $\mathrm{I}=$ ipilimumab; $\mathrm{C}=$ cabozantinib; Len = Lenvatinib; Pem = pembrolizumab; eve $=$ everolimus; Atezo $=$ atezolizumab;

The quality of life analyses of the CABOSUN trial [10] evaluated the Q-TWiST (Quality-adjusted survival Time without Symptoms of disease or Toxicity) also demonstrated the quality of life advantage from the use of cabozantinib compared to the previous standard of care, sunitinib. Sunitinib had been the main VEGF TKI used since its FDA approval in 2006 [11], hence, the de facto comparator arm for all the contemporary first-line clinical trials for advanced and metastatic RCC. While VEGF TKI monotherapy is fast shrinking and narrowing as a treatment option for first-line therapy in metastatic RCC, the Checkmate 214 trial shows that patients with favorable risk disease per the International Metastatic Renal Cell Carcinoma Database Consortium (IMDC) criteria tend to still do better with sunitinib monotherapy compared to IO combination therapy. Therefore, extrapolation has been made to the ALLIANCE-led CABOSUN trial, which while technically enrolled 157 patients with intermediaterisk and poor-risk disease only and randomized to either cabozantinib or sunitinib, the FDA approval and label encompasses all patients in first-line, without distinction regarding their risk of disease, given that the primary endpoint of progression-free survival was met at 8.6 months $(95 \%$ confidence interval [CI] $6.8-14.0)$ for cabozantinib compared to sunitinib at 5.3 months $(95 \%$ CI $3.0-8.2$ ) at a hazard ratio [HR] 0.48 [95\% CI $0.31-$ $0.74][8,12,13]$.

The ability to tolerate side-effects of VEGF TKIs are important, whether used as monotherapy or in combination with CPI. Different measures of quality of life (QOL) analyses have been attempted, and the recent analyses [10] as well as interpretation of this data [14], offered some insights as to the evaluation of the impact of QOL and tolerance to these drugs.

The Q-TWiST measures have been used for in clinical trials to add perspective and assess toxicities of therapy as it relates to the clinical parameters of benefit such as PFS [15]. Just as important to grading the toxicity is evaluating patients' perceptions regarding clinical symptoms [16], but ultimately to comparing to current standards of care [17], as well as formally using different gauges of response as well as toxicity to dictate the value and decrements in quality of life [18].

The Q-TWIST analyses for the CABOSUN trial 
[10] is but one analysis of such quality of life parameters which looked at the time without symptoms of disease or toxicity defined as the "TWiST", the "TOX" or the time without disease progression and without any development of toxicity as well as the "REL" or relapse, time after disease progression until death. The parameters were measured as utility scores which ranged from 0 to 1 , with a point scale of 1 referring to one's perfect health while a score of 0 equating to death. Not surprisingly, the CABOSUN trial reflected statistically significant difference within all parameters that was in favor of cabozantinib over sunitinib, despite both drugs being VEGF TKIs. Different VEGF TKIs are also expected to yield different toxicity findings. Further analyses of toxicity were extrapolated from the METEOR trial [19], which is a second-line trial assessing the difference between cabozantinib and everolimus post-TKI treatment. Other Q-TWiST analyses from different trials such as the comparison between sunitinib and pazopanib showed favorable results for pazopanib [20]. However, VEGF TKI monotherapy would now be relevant for use only in a relatively small population of metastatic RCC patients, typically those with favorable risk disease per IMDC criteria, who would be appropriate for VEGF TKI monotherapy alone. Majority of patients would be otherwise suitable for at least an $\mathrm{IO} / \mathrm{IO}$ combination or an IO/TKI combination therapy if they have at least intermediate-risk or poor-risk disease. Therefore, emphasizing QOL analyses for the more contemporary trials would be of relevant importance such as the one in the Checkmate 214 trial [2], with the Q-TWiST analyses of nivolumab and ipilimumab showing improvement over sunitinib with 3.5 months with a relative gain of $15.1 \%$ compared to sunitinib [21]. There has been reported Q-TWiST analyses for other second-line therapy trials such as the comparison between nivolumab and everolimus in the CheckMate 025 trial in favor of nivolumab [22] and the phase III trial on temsirolimus over interferon [23] or sunitinib over interferon [24], all of which closely followed the primary endpoint results of the corresponding trials as well. Beyond Q-TWiST analyses, it would also be helpful to evaluate patient reported outcomes (PROs) as additional gauge for understanding patients' perception and tolerance of these regimens. For instance, the Checkmate 214 trial showed that treatment with nivolumab and ipilimumab showed less deterioration of symptoms and health-related quality of life overall compared to the standard of care arm, sunitinib [25].

It would be interesting to note how the newer VEGF TKIs that have just been approved such as tivozanib [26], would be placed in sequencing for third line therapy and beyond, along with QOL analyses. While there will unlikely be data to inform the most optimal sequencing approach after failure from prior VEGF TKI/ IO combination therapy or IO/IO therapy, the subsequent treatment approach may hinge upon the toxicities incurred from first-line therapy as well as duration or durability of response from first-line therapy. In addition, further evaluation and QOL analyses for the appropriate secondline therapy would also be helpful to guide future therapy.

\section{CONFLICTS OF INTEREST}

The author declare no potential conflicts of interest.

\section{REFERENCES}

1. Motzer RJ, Hutson TE, Cella D, Reeves J, Hawkins R, Guo J, Nathan P, Staehler M, de Souza P, Merchan JR, Boleti E, Fife K, Jin J, et al. Pazopanib versus sunitinib in metastatic renal-cell carcinoma. N Engl J Med. 2013; 369:722-31. https://doi.org/10.1056/NEJMoa1303989. PMID:23964934

2. Motzer RJ, Tannir NM, McDermott DF, Arén Frontera O, Melichar B, Choueiri TK, Plimack ER, Barthélémy P, Porta C, George S, Powles T, Donskov F, Neiman V, et al, and CheckMate 214 Investigators. Nivolumab plus Ipilimumab versus Sunitinib in Advanced Renal-Cell Carcinoma. N Engl J Med. 2018; 378:1277-90. https://doi.org/10.1056/ NEJMoa1712126. PMID:29562145

3. Motzer RJ, Rini BI, McDermott DF, Arén Frontera O, Hammers HJ, Carducci MA, Salman P, Escudier B, Beuselinck B, Amin A, Porta C, George S, Neiman V, et al, and CheckMate 214 investigators. Nivolumab plus ipilimumab versus sunitinib in first-line treatment for advanced renal cell carcinoma: extended follow-up of efficacy and safety results from a randomised, controlled, phase 3 trial. Lancet Oncol. 2019; 20:1370-85. https://doi. org/10.1016/S1470-2045(19)30413-9. PMID:31427204

4. Rini BI, Powles T, Atkins MB, Escudier B, McDermott DF, Suarez C, Bracarda S, Stadler WM, Donskov F, Lee JL, Hawkins R, Ravaud A, Alekseev B, et al, and IMmotion151 Study Group. Atezolizumab plus bevacizumab versus sunitinib in patients with previously untreated metastatic renal cell carcinoma (IMmotion151): a multicentre, open-label, phase 3, randomised controlled trial. Lancet. 2019; 393:2404-15. https://doi.org/10.1016/S01406736(19)30723-8. PMID:31079938

5. Rini BI, Plimack ER, Stus V, Gafanov R, Hawkins R, Nosov D, Pouliot F, Alekseev B, Soulières D, Melichar B, Vynnychenko I, Kryzhanivska A, Bondarenko I, et al, and KEYNOTE-426 Investigators. Pembrolizumab plus Axitinib versus Sunitinib for Advanced Renal-Cell Carcinoma. N Engl J Med. 2019; 380:1116-27. https://doi. org/10.1056/NEJMoa1816714. PMID:30779529

6. Motzer RJ, Penkov K, Haanen J, Rini B, Albiges L, Campbell MT, Venugopal B, Kollmannsberger C, Negrier 
S, Uemura M, Lee JL, Vasiliev A, Miller WH Jr, et al. Avelumab plus Axitinib versus Sunitinib for Advanced Renal-Cell Carcinoma. N Engl J Med. 2019; 380:1103-15. https://doi.org/10.1056/NEJMoa1816047. PMID:30779531

7. Choueiri TK, Powles T, Burotto M, Escudier B, Bourlon MT, Zurawski B, Oyervides Juárez VM, Hsieh JJ, Basso U, Shah AY, Suárez C, Hamzaj A, Goh JC, et al, and CheckMate 9ER Investigators. Nivolumab plus Cabozantinib versus Sunitinib for Advanced Renal-Cell Carcinoma. N Engl J Med. 2021; 384:829-41. https://doi. org/10.1056/NEJMoa2026982. PMID:33657295

8. Choueiri TK, Halabi S, Sanford BL, Hahn O, Michaelson MD, Walsh MK, Feldman DR, Olencki T, Picus J, Small EJ, Dakhil S, George DJ, Morris MJ. Cabozantinib Versus Sunitinib As Initial Targeted Therapy for Patients With Metastatic Renal Cell Carcinoma of Poor or Intermediate Risk: The Alliance A031203 CABOSUN Trial. J Clin Oncol. 2017; 35:591-97. https://doi.org/10.1200/ JCO.2016.70.7398. PMID:28199818

9. Motzer R, Alekseev B, Rha SY, Porta C, Eto M, Powles T, Grünwald V, Hutson TE, Kopyltsov E, Méndez-Vidal MJ, Kozlov V, Alyasova A, Hong SH, et al, and CLEAR Trial Investigators. Lenvatinib plus Pembrolizumab or Everolimus for Advanced Renal Cell Carcinoma. N Engl J Med. 2021; https://doi.org/10.1056/NEJMoa2035716. PMID:33616314

10. Chen RC, Choueiri TK, Feuilly M, Meng J, Lister J, Marteau F, Falchook AD, Morris MJ, George DJ, Feldman DR. Quality-adjusted survival with first-line cabozantinib or sunitinib for advanced renal cell carcinoma in the CABOSUN randomized clinical trial (Alliance). Cancer. 2020; 126:5311-18. https://doi.org/10.1002/cncr.33169. PMID:33022096

11. Motzer RJ, Escudier B, Gannon A, Figlin RA. Sunitinib: Ten Years of Successful Clinical Use and Study in Advanced Renal Cell Carcinoma. Oncologist. 2017; 22:41-52. https:// doi.org/10.1634/theoncologist.2016-0197. PMID:27807302

12. Choueiri TK, Hessel C, Halabi S, Sanford B, Michaelson MD, Hahn O, Walsh M, Olencki T, Picus J, Small EJ, Dakhil S, Feldman DR, Mangeshkar M, et al. Cabozantinib versus sunitinib as initial therapy for metastatic renal cell carcinoma of intermediate or poor risk (Alliance A031203 CABOSUN randomised trial): progression-free survival by independent review and overall survival update. Eur J Cancer. 2018; 94:115-25. https://doi.org/10.1016/j. ejca.2018.02.012. PMID:29550566

13. FDA. FDA grants regular approval to Cabometyx for firstline treatment of advanced renal cell carcinoma. December 2017

14. Aragon-Ching JB, Madan RA. Life under the CABOSUN: cabozantinib improves quality-adjusted survival in comparison with sunitinib. Cancer. 2020; 126:5210-12. https://doi.org/10.1002/cncr.33168. PMID:33022092
15. Glasziou PP, Simes RJ, Gelber RD. Quality adjusted survival analysis. Stat Med. 1990; 9:1259-76. https://doi. org/10.1002/sim.4780091106. PMID:2277877

16. Priestman TJ, Baum M. Evaluation of quality of life in patients receiving treatment for advanced breast cancer. Lancet. 1976; 1:899-900. https://doi.org/10.1016/S01406736(76)92112-7. PMID:58161

17. Gelber RD, Goldhirsch A, Cole BF, Wieand HS, Schroeder G, Krook JE. A quality-adjusted time without symptoms or toxicity (Q-TWiST) analysis of adjuvant radiation therapy and chemotherapy for resectable rectal cancer. J Natl Cancer Inst. 1996; 88:1039-45. https://doi.org/10.1093/ jnci/88.15.1039. PMID:8683634

18. Swinburn P, Lloyd A, Nathan P, Choueiri TK, Cella D, Neary MP. Elicitation of health state utilities in metastatic renal cell carcinoma. Curr Med Res Opin. 2010; 26:1091-96. https://doi.org/10.1185/03007991003712258. PMID:20225993

19. Choueiri TK, Escudier B, Powles T, Tannir NM, Mainwaring PN, Rini BI, Hammers HJ, Donskov F, Roth BJ, Peltola K, Lee JL, Heng DY, Schmidinger M, et al, and METEOR investigators. Cabozantinib versus everolimus in advanced renal cell carcinoma (METEOR): final results from a randomised, open-label, phase 3 trial. Lancet Oncol. 2016; 17:917-27. https://doi.org/10.1016/S14702045(16)30107-3. PMID:27279544

20. Beaumont JL, Salsman JM, Diaz J, Deen KC, McCann L, Powles T, Hackshaw MD, Motzer RJ, Cella D. Qualityadjusted time without symptoms or toxicity analysis of pazopanib versus sunitinib in patients with renal cell carcinoma. Cancer. 2016; 122:1108-15. https://doi. org/10.1002/cncr.29888. PMID:27000445

21. Shah R, Botteman M, Kwon Y, Gooden KM, Cella D, Motzer R. PCN264 Quality adjusted time without symptoms of disease progression or toxicity (Q-TWiST) of nivolumab plus ipilimumab (Nivo + Ipi) vs sunitinib (SUN) among untreated advanced renal cell carcinoma (ARCC) patients (Patients) with intermediate or poor prognostic risk. Value Health. 2019; 22:S106. https://doi.org/10.1016/j. jval.2019.04.385.

22. Shah R, Botteman M, Solem CT, Luo L, Doan J, Cella D, Motzer RJ. A Quality-adjusted Time Without Symptoms or Toxicity (Q-TWiST) Analysis of Nivolumab Versus Everolimus in Advanced Renal Cell Carcinoma (aRCC). Clin Genitourin Cancer. 2019; 17:356-365.e1. https://doi. org/10.1016/j.clgc.2019.05.010. PMID:31272883

23. Zbrozek AS, Hudes G, Levy D, Strahs A, Berkenblit A, DeMarinis R, Parasuraman S. Q-TWiST analysis of patients receiving temsirolimus or interferon alpha for treatment of advanced renal cell carcinoma. Pharmacoeconomics. 2010; 28:577-84. https://doi.org/10.2165/11535290-00000000000000. PMID:20550223

24. Patil S, Figlin RA, Hutson TE, Michaelson MD, Negrier 
S, Kim ST, Huang X, Motzer RJ. Q-TWiST analysis to estimate overall benefit for patients with metastatic renal cell carcinoma treated in a phase III trial of sunitinib vs interferon- $\alpha$. Br J Cancer. 2012; 106:1587-90. https://doi. org/10.1038/bjc.2012.149. PMID:22568998

25. Cella D, Grünwald V, Escudier B, Hammers HJ, George S, Nathan P, Grimm MO, Rini BI, Doan J, Ivanescu C, Paty J, Mekan S, Motzer RJ. Patient-reported outcomes of patients with advanced renal cell carcinoma treated with nivolumab plus ipilimumab versus sunitinib (CheckMate 214): a randomised, phase 3 trial. Lancet Oncol. 2019; 20:297310. https://doi.org/10.1016/S1470-2045(18)30778-2. PMID:30658932

26. Rini BI, Pal SK, Escudier BJ, Atkins MB, Hutson TE, Porta C, Verzoni E, Needle MN, McDermott DF. Tivozanib versus sorafenib in patients with advanced renal cell carcinoma (TIVO-3): a phase 3, multicentre, randomised, controlled, open-label study. Lancet Oncol. 2020; 21:95-104. https:// doi.org/10.1016/S1470-2045(19)30735-1. PMID:31810797 